\title{
Inverse Perspective in Cézanne's Art
}

Ivana J. Marcikić

PhD Proffesor

Department of Applied Graphic University of Art in Belgrade Faculty of Applied Arts

Marijana V. Paunović

Ass. Professor

Department of Applied Graphic University of Art in Belgrade Faculty of Applied Arts
In a special way, "Cézanne's wedge" allows the model of inverse perspective to be used for the representation of space and objects in painting. As a bridge between the ancient style of "dividing" construction and Renaissance perspective, inverse perspective as an important projection model, due to the fact that it represents an object with the minimum of hidden parts, compared to representation in any other system of projection. The optical-physiological properties of the optic apparatus, the fact that we perceive space from two points, inverse perspective, which implies a multiocular view with many binocular pairs of points, are close to natural vision. Popular-culture's need for the sensation of $3 D$ space in a picture separates artistic creativity from the individual expression of the artist, his intuitive geometry and its spirit of revised reality, which are important characteristics of every masterpiece.

This paper analyses the inverse perspective and its effects in the representation of space in Cézanne's paintings.

Keywords: space in painting; inverse perspective; Cézanne's wedge; scientific perspective; view point; vanishing point

\section{INTRODUCTION}

Geometric approaches to theoretic explanations of the visual effects in painted masterpieces, including those of Cezanne, are absent. The inverse perspective in Cezanne's work has not, to date, been analysed.

Western theorists discuss visual art quite generally and almost casually when considering Cezanne's paintings. The reason could be that they have insufficient knowledge and recognition of inverse perspective as a projection system of medieval Eastern painting. Thus, the meaning of the "new" space in a painting is attributed exclusively to the Western renaissance perspective.

As the effects of inverse space and that space's inverse projection are present in all thematic areas of Cezanne's paintings (still life, portraits, landscapes), this paper analyses the areas of constructive geometry, geometrical optics and optical-physiological perspective, according to the stated sections.

\section{CÉZANNE'S LANDSCAPES}

Cézanne's landscapes appear to be scenes from a theatrical space with an emphatically shallow stage depth (Fig.1). That is why the image "expands" along the horizontal, the foreground is realistic, and everything located behind appears as though it is depicted on a stage curtain placed in the background of the composition.

The result is a new space in the painting. The renaissance perspective is absent, depth is "abolished", jet not volume, there is no accentuated vanishing point,

Received: June 2016, Accepted: November 2016

Correspondence to: Ivana Marcikic, PhD Professor Department of Applied Graphic, University of Art in Belgrade, Faculty of Applied Arts

E-mail: marcikicivana@yahoo.com doi:10.5937/fmet1702301M

(C) Faculty of Mechanical Engineering, Belgrade. All rights reserved but there is an aerial perspective created by the tonal scale of the colour blue. The artistic tools evoke a landscape of extraordinary warmth.

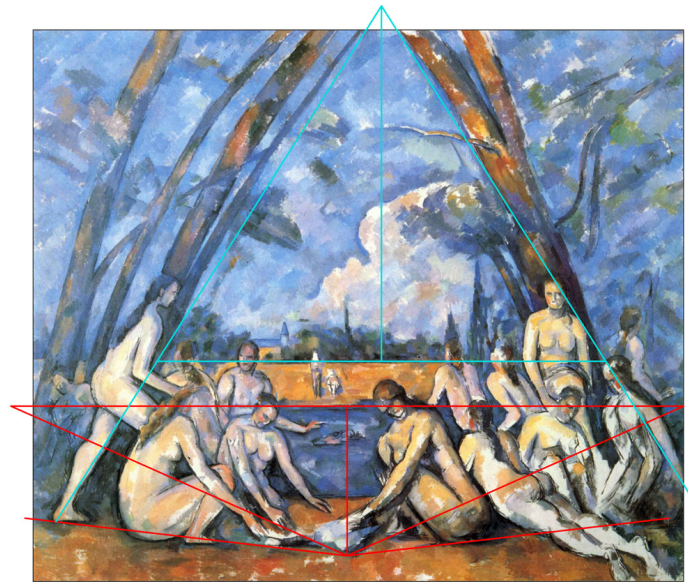

Figure 1. Women Bathers, Paul Cézanne, 1898-1905, Philadelphia Museum of Art (Source: Schapiro)

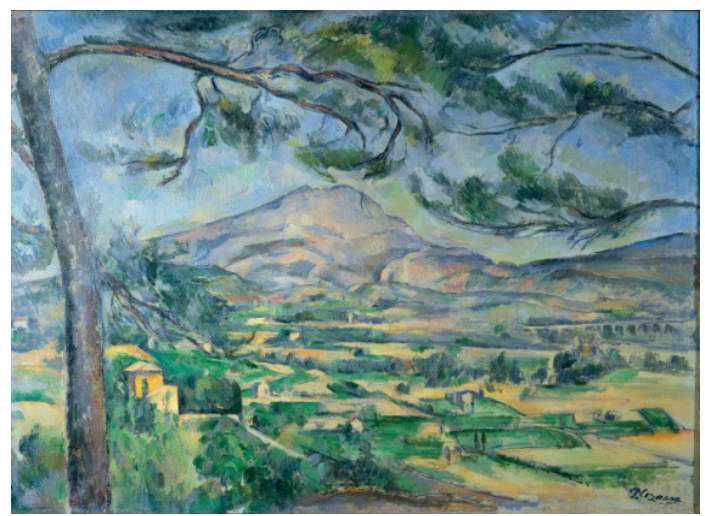

Figure 2. Mont Sainte-Victoire, Paul Cézanne,1885-1887, Courtauld Institute of Art, London (Source: Schapiro)

A comparative analysis reveals the difference between depicting Cézanne's (Fig.2) and Rubens' (Fig.3) landscapes, depicted here.

FME Transactions (2071) 45, 301-306 301 


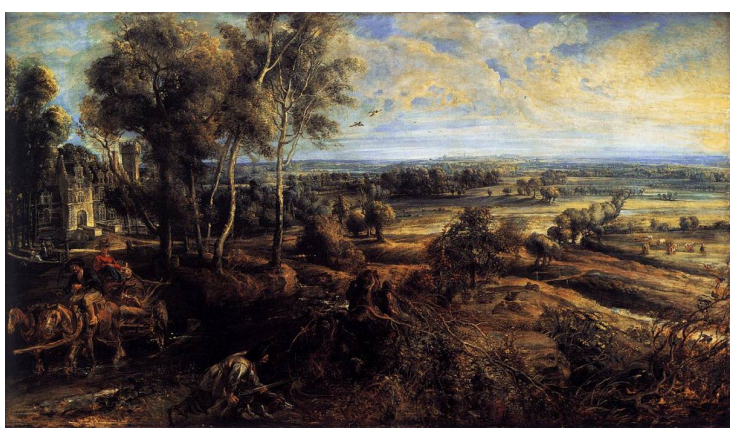

Figure 3. A View of Het Steen in the Early Morning, Peter Paul Rubens, 1636, National Gallery, London (Source: Weltonová)

In the painting of Paul Cézanne (Fig.2), the tree in the foreground frames the composition with its trunk and top and it makes us experience the other elements in the painting as if they are being viewed through a window. The horizontal lines of the roads and the viaduct in the frontal perspective, as well as the entire composition's horizontal line, are superimposed onto the vertical line of the tree. The tree doesn't disrupt the image with its pure verticality. The treetop unfolds over the landscape, without blocking any of its parts, but creating new and exciting elements in the sky. The effect of accentuated depth and spatial enlargement is achieved. "Lines perpendicular to that horizon give depth. But for us men, nature has more depth than surface, hence the need to introduce our vibrations of light, represented by reds and yellows, enough blue tints to give a feeling of air." From Cézanne's letter to Emile Bernard, April 15, 1904. Francis Jourdain, Cézanne, Paris 1950. Pg.11.

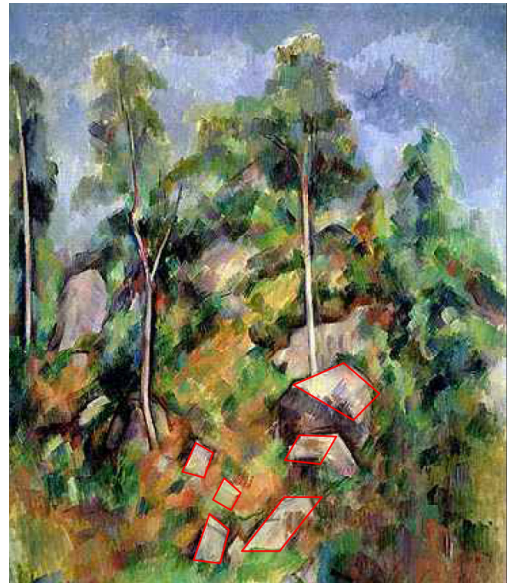

Figure 4. Rocks and Trees, Paul Cézanne, 1904, Philadelphia Museum of Art (Source:

http://www.barnesfoundation.org/collections/artcollection/object/5016/rocks-and-trees-rochers-et-arbres), analysis of authors

Cézanne's bas-relief (Fig.4) carries with it the effects of a Byzantine fresco (Fig.5), removing the barrier between the space of the gallery and the painting, directing the observer's attention to individual objects; each represented by their most important characteristics, in differently selected projections used in the same composition.

Thinking that there is a "single pure truth of things in painting", Cézanne intuitively comes up with geometric solutions characteristic of frescos or icons from the medieval period (Fig.5). He depicts horizontal surfaces (Fig.4) so as to create the impression that they are "falling" towards us. Their edges, which are perpendicular to the painting's surface, begin to separate from each other as their distance increases.

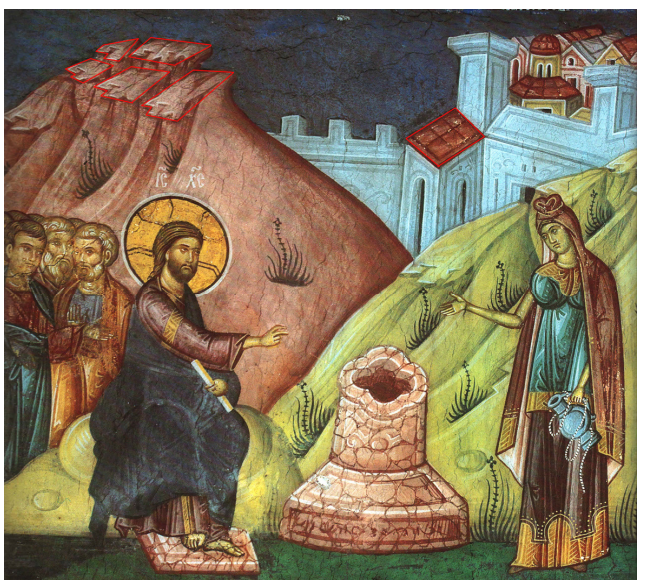

Figure 5. Frescoe in narthex of Arch. Danilo II (detail), 1565, The Patriarchate of Peć, (Source: Đurić, at al.), analysis of authors

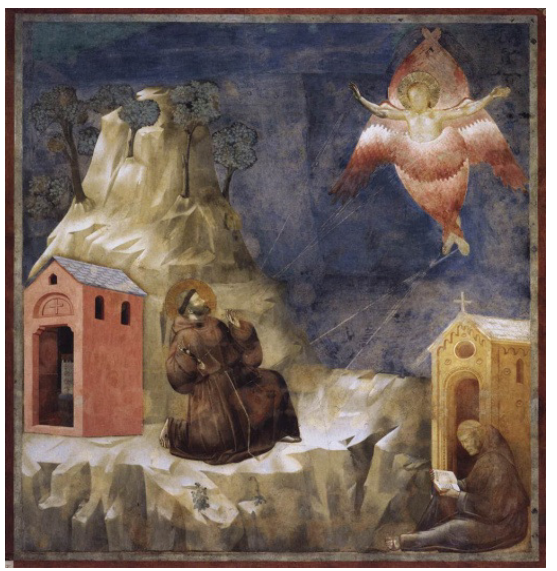

Figure 6. Stigmatization of St Francis, Giotto di Bondone, Basilica of St. Francis Assisi, Italy, 1297-1300 (Source: http://www.encyclopedie.bseditions.fr/image/article/image/l TPEIPRIGIOTTOB074.jpg)

The choice of projection, one in which an architectural object is depicted, is uncannily similar for both Giotto (Fig.6) and Cézanne (Fig.7).

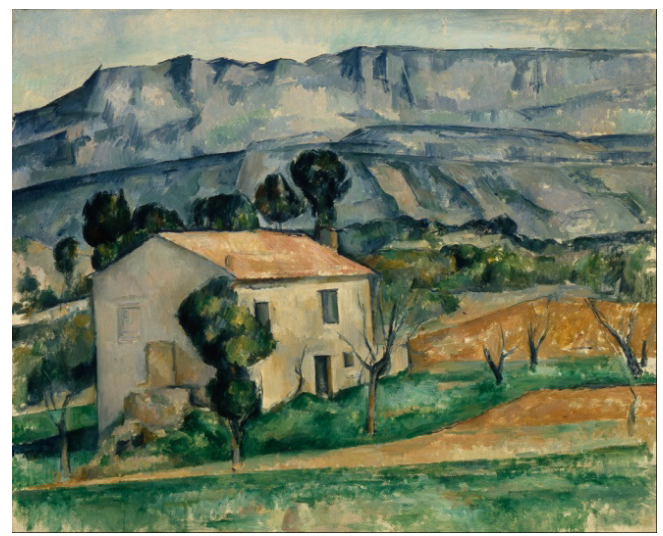

Figure 7. House in Provence, Paul Cézanne,1885-1886, The John Herron Art Institute, Indianapolis (Source: Schapiro)

Mirabeau, the grandest boulevard in Aix-enProvence, has lines of trees on either side, whose tops come together to create a verdant tunnel (Fig.8). As can 
be expected, the triangular shape inspired Cézanne. He uses isosceles triangles in his compositions to position figures, objects and, most frequently, to depict landscapes (Fig.9).

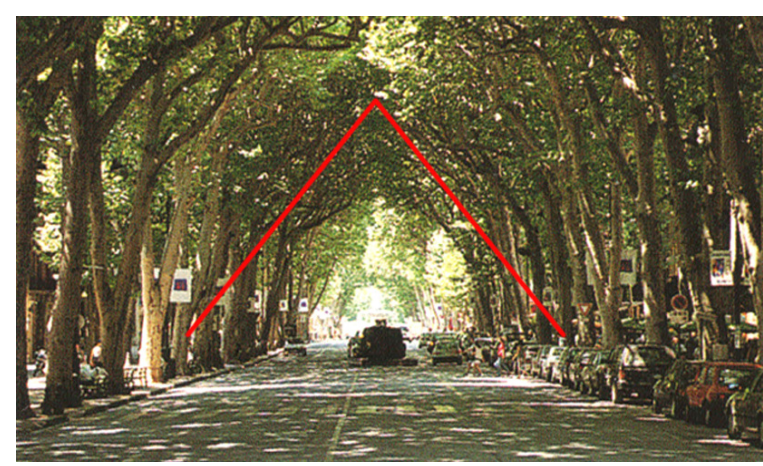

Figure 8. The cours Mirabeau, grandest of Aix's boulevards, Provence, (Source: Williams), analysis of authors

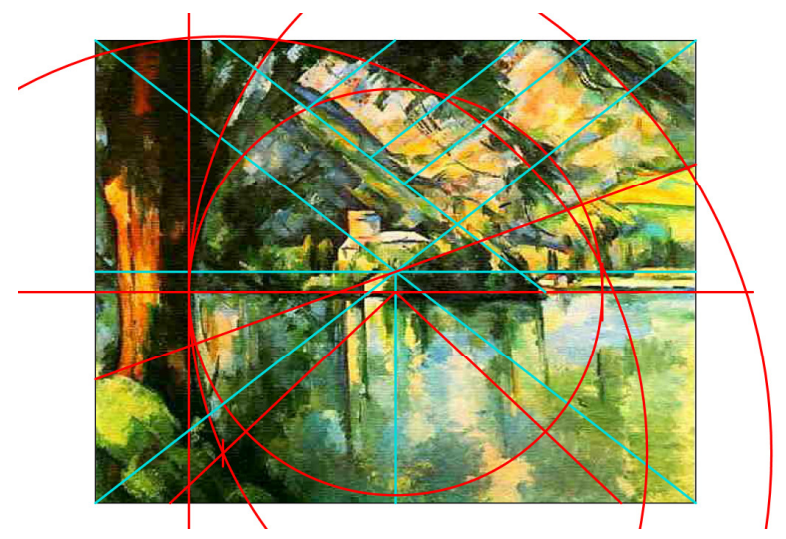

Figure 9. The Lac d'Annecy, Paul Cézanne, 1896, Courtauld Institute of Art, London, (Source: http://www.paul-cezanne.org/The-Lac-D-Annecy.html), analysis of authors

The water's (lake shore) horizontal line geometrically divides the composition (Fig.9). With it, Cézanne seems to want to stress the duplication of the motif, i.e. the orthogonal symmetry of the landscape and its reflection on the water's surface. The shape of the tree trunk exhibits the above-mentioned symmetry along the same horizontal axis, even though it is set apart at the front, in the foreground. The lower and right-side edges of the painting intersect the lake's surface and enlarge it. The isosceles triangle, so often used in Cézanne's compositional scheme, is created here with the boundary line of the water's green sections and the painting's lower edge, directing the observer's gaze towards the geometric centre where the composition's diagonals intersect. By replacing the orthogonal line, the lines of the triangle intensify the depth of the depicted landscape. Provence's tree tops are Mediterranean; imposing with their green, almost black, colour. The frames of Cézanne's landscapes are often made from these branches, which focus the observer's attention to "behind" the landscape, providing depth, along with the effect of "looking through". The bases of the trunks are connected (Fig.10) by two lines which intersect "in front" of the painting, giving the effect of inverse volume. Thus the architectural object's facadecontaining background is enlarged, compared to the foreground.

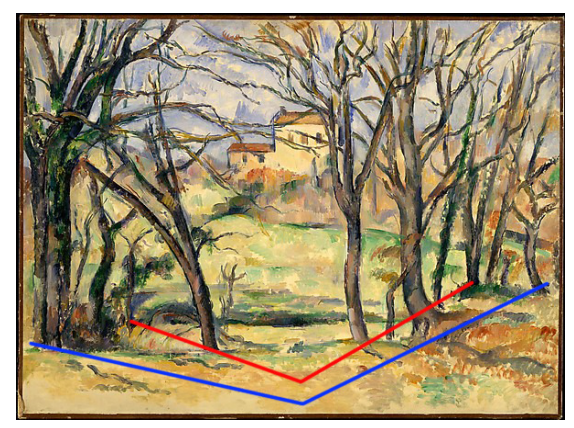

Figure 10. Trees and Houses, Paul Cézanne,1885-1887, Lehman Collection, New York, (Source: Taylor), analysis of authors

The ability to focus on shape and colour, the art of separating the consequential from the accompanying impurities, which interfere with the impression he wants to make on the observer, are all part of the secret of Cézanne's artistic genius.

Provence, "the Lord's garden", was as if made to serve as a theme for the greatest painters of the $19^{\text {th }}$ and $20^{\text {th }}$ centuries, and it stimulated Cézanne's use of colour to fill the entire spectrum. Its flower fields of lavender, the range of the green hues of treetops, the most diverse multitude of unique floral specimens, the colour of the water, lakes and rivers, acting like natural mirrors, the remains of Roman architecture (aqueducts and viaducts), appear today less as accidental decor, and more as the only possible environment for each of Cézanne's landscapes.

"Cézanne embodied spirit of France in his work, yet he never painted an historical subject in his life. He was the logical result of generations of culture and high thinking. He loved the soil, and his work lives and speakers of a great people... An artist may belong wholly to his country and yet be claimed by the universe." Everett Carroll Maxwell, artist, 1917. (Stavitsky, G., at al. 2009:52)

\section{CÉZANNE'S STILL LIFES}

In contrast to the opinion of the esteemed theoretician and art critic, the extraordinary connoisseur of visual arts, Professor Lazar Trifunović, we consider that the individual objects in Cézanne's paintings aren't deformed, but have an unusual spatial layout and are revealed by deliberately "moving" the eye of the person who made them part of the painting, as well as our own, observing them.

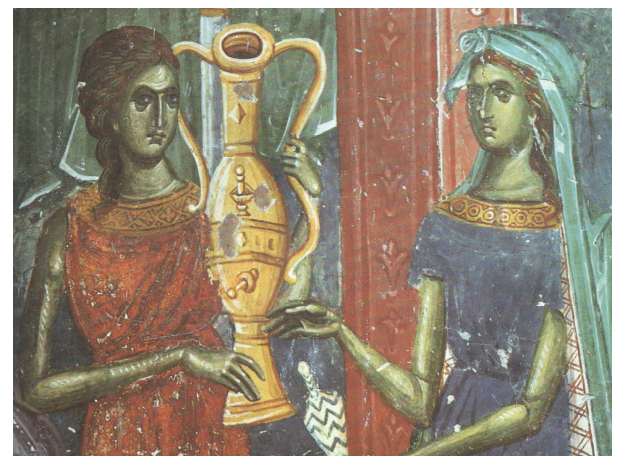

Figure 11. Birth of Mother of God (detail) altar-southern wall, around 1345, church of St. Demetrius, The Patriarchate of Peć, (Source: Đurić, at al.) 
Cézanne doesn't use a geometrical shadow, but instead one he seems to have "borrowed" from the Peć Patriarchy fresco which depicts a maidenly face and a vessel filled with water (Fig.11); its objects are neither elongated, nor shortened, but just "turned" toward us in order for us to better understand their shape. He achieves the "kinetic eye" effect through the use of inverse perspective, revealing to us the surfaces that are important for defining and displaying specific segments or the entirety of the composition, which would be impossible to perceive through the use of the Renaissance perspective (Fig.12). Cézanne is familiar with the optical-physiological perspective and uses the phenomenon of successive image perception by making us change our viewpoint, thereby dictating the observer's movements. We can recall that the Byzantine perspective has the same effect, as well as Serbian medieval painting.

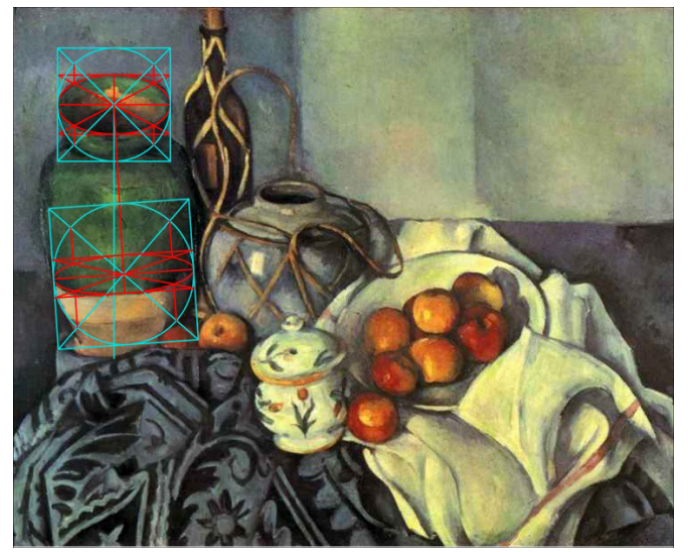

Figure 12. Still life with apples, Paul Cézanne, 1893 - 1894, J. Paul Getty Museum, Los Angeles (The Getty Centre), (Source: http://www.paul-cezanne.org/home-1-96-1-0.html), analysis of authors

The painting, "Basket of Apples" (Fig.13), in which the stand, known as Cézanne's wedge, is noticeable under the fruit basket, dispels any doubts.

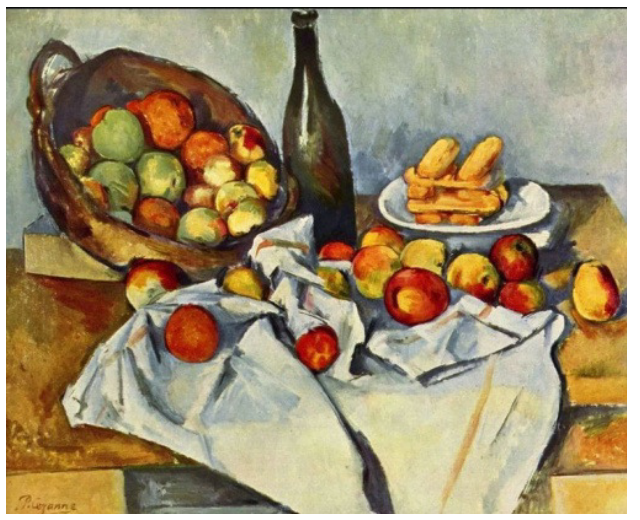

Figure 13. Still life with Basket of Apples, 1890-1894, Paul Cézanne, Art Institute of Chicago IL (Source: Schapiro)

Cézanne used these kinds of stands, of varying sizes, (Fig.14) in order to tilt objects he painted, towards himself. He placed them in this position to not only make them more visible, but as though he was an iconographer, providing the observer with as much visual information as possible. Cézanne's wedge confirms that he painted objects according to models. He consistently replicated their spatial layout on the canvas. The effect he created in this manner is the same as the one created by using the inverse perspective. A detailed analysis of the constructed contours (ellipses) of both circular plates proves that they are in different planes; with the larger one belonging to the plane which slants on a steep angle towards the table's surface, and the other following the horizontal surface's angle. Geometric analysis of the painting's third surface of revolution surface (Fig.14, detail) confirms the use of several projection systems for the same object. A deviation from the geometric method of displaying rotational forms in axonometry is constructively demonstrated.
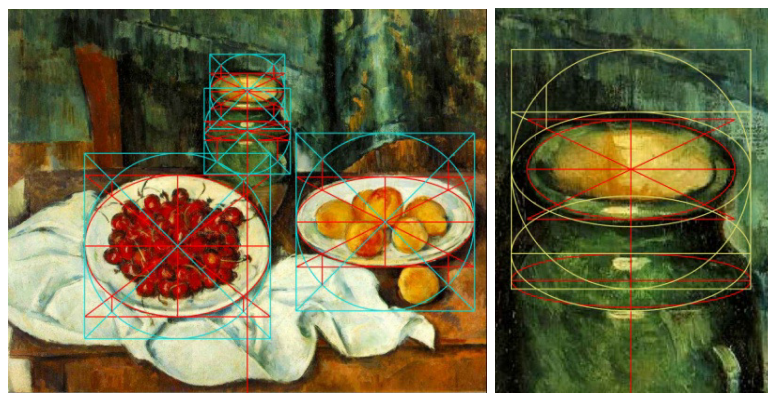

Figure 14. Still Life with a Plate of Cherries and detail, Paul Cézanne,1885-1887, Los Angeles County Museum of Art; Venturi no. 498, analysis of authors

The surface of revolution (Fig.15) is analysed by geometric restitution and the conclusion reached is that the rotation axis in the painting is deliberately skewed towards the vertical line, slanted in the direction of the observer with the intention of achieving the effect of defining the circle-parallels which, in the frontal perspective, would be emphatically shortened, almost imperceptible as a projection of the circle, if the vertically placed axis was retained.

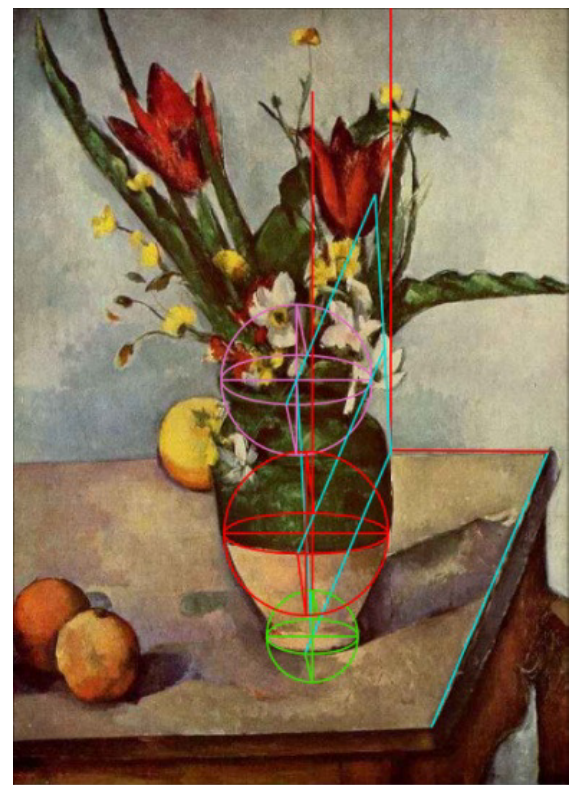

Figure 15. Tulips and Apples, Paul Cézanne, 1890-1893, Art Institute of Chicago IL (Source: Schapiro), analysis of authors

When he, almost constructively, with geometric precision sets up the parallel lines of the cuboid, most often as the edges of the table, which itself is the pedestal of still lifes, he intuitively re-establishes the effect of spatial inversion by resolving shadows of different thicknesses (Fig.16). 


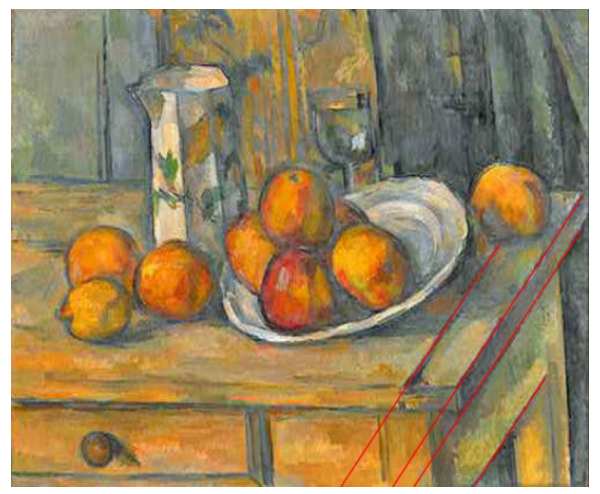

Figure 16. Still Life with Milk Jug and Fruit, Paul Cézanne, 1900, National Gallery of Art, Washington D.C. (Source: https://www.artsy.net/artwork/paul-cezanne-still-life-withmilk-jug-and-fruit), analysis of authors

Cézanne also directs his artistic energy towards the search for what is quite unnecessary in the objects that have been chosen to be transplanted onto the canvas, so as to "disrupt" the composition, to "ruin" adjacent objects, to "disturb" the harmony of the whole, to "derange" the harmony of colour.

A man's destiny is this influence of everything from his surroundings on an individual figure or object. We do not see or know anything, unless we make comparisons: big-small, beautiful-ugly, static-dynamic, real-imaginary and good-bad.

The breadth of Cézanne's character, this philosophy of "what is complex needs to be made simple", has opened the way towards a new painting. His preference for using the same objects, set up differently in relation to each other, speaks of the need to constantly study and instinctively search for, as he calls it, "the truth in painting". However, his paintings are, individually, examples of discovering new subtleties within theoretical conclusions.

As if spending his entire life "mocking" the board of the École des Beaux-Arts, who turned his admission down, Cézanne demonstrates with each new painting bearing the same theme, what he can do and his sense of using colours and shapes, which they, before he appeared, knew nothing about. In creating a still life, the contrast achieved through light and shadows indicates the influence of Velasquez's and Caravaggio's works, which Cézanne studied in the Louvre.

As Professor Trifunović writes, the works of Lobachevsky, Gauss and Ryman, concerning the spatial curvature of the universe and its non-Euclidian geometry, were certainly known to Cézanne, but we think that he was wrong to conclude that, because of this, Cézanne constructed "a specific space which develops through the planimetric conquest of painted surfaces, as opposed to the static and three-dimensional Euclidian lacuna..." (Trifunović, 1981:35)

Our arguments take into account the fact that Euclidian space is, still today, the only one we inhabit, move in, think in and can measure with a divider and ruler. All other spaces are from an "irrational universe" known only to pure science. Our imagination can "curve" a plane, but we cannot as much as walk on such a surface.

"Cézanne's complex theoretic constructs were preserved in letters written to E. Bernard and Dr.
Gascau”. Lazar Trifunović, Slikarski Pravci XX veka, Priština / Beograd, 1981, Pg. 256.

\section{CÉZANNE'S FIGURES}

Just like in a theatre scene, Cézanne positions two figures that are actively participating in the action, by displaying their profiles in a psychological relationship (Fig.17).

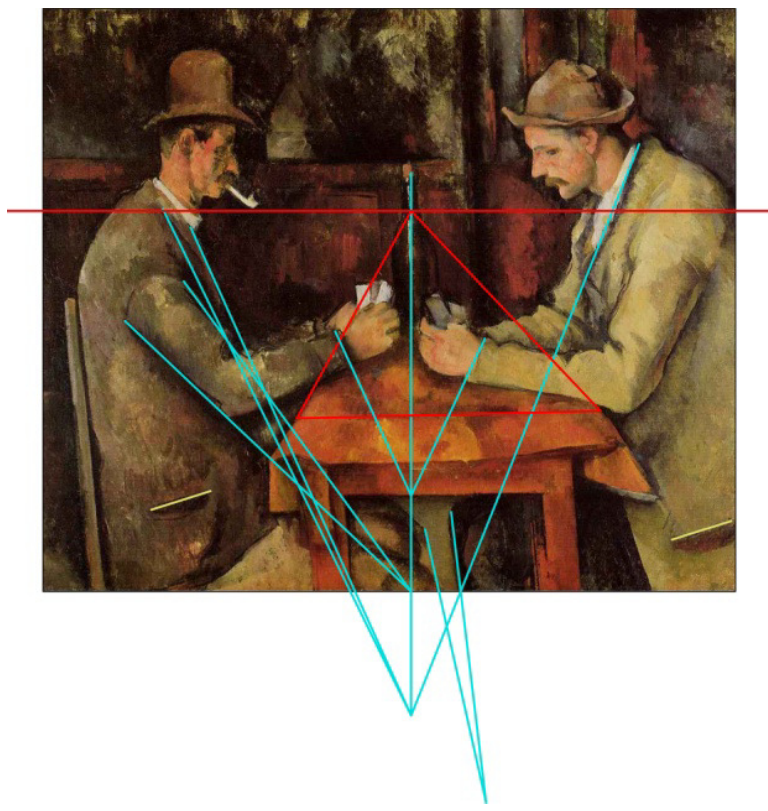

Figure 17. The Card Players, 1890-1892, The Louvre, Paris (Source: Schapiro), analysis of authors

He again uses the inverse projection, directing the main contours of both figures towards the observer. We are introduced to the space of the painting in the simplest way possible. The inverse perspective, combined with the frontal perspective, is also used here. The result is an emphasised dramatic moment. In the example of one figure in a twisted bodily posture (Fig.18), Cézanne turns the face towards the front, thereby creating a direct communication. He again uses the elements of inverse projection, which the analysis (Fig.18) indicates.

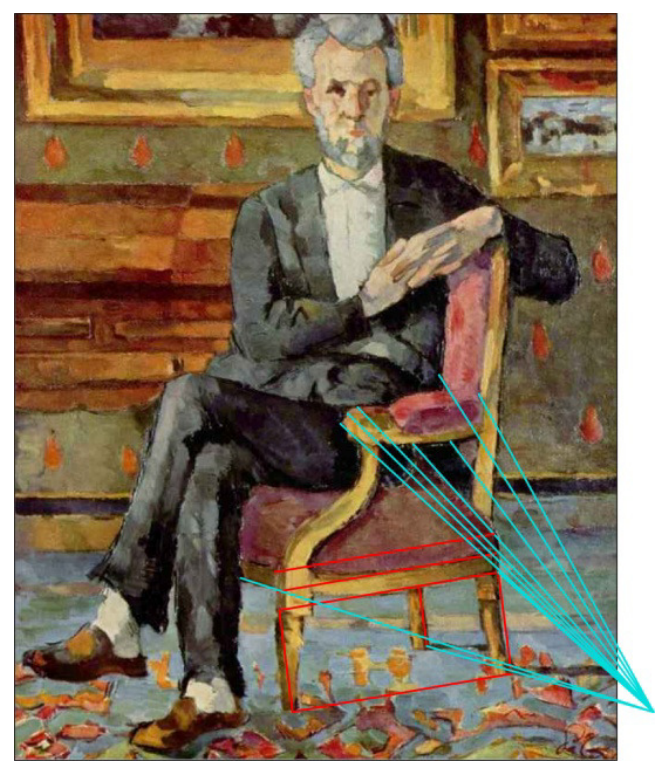

Figure 18. Chocquet Seated, Paul Cézanne, 1877, Gallery of Fine Arts, Ohio (Source: Schapiro), analysis of authors 


\section{CONCLUSION}

The magnitude of Cézanne's idea and his "truth of things" lie in the freedom to combine antique perspective, Egyptian projection, Giotto's parallel projection, inverse perspective and especially the oftenused axonometry. He takes them as one would take tools off "his atelier's shelf" and thoughtfully combines them to create what the artist sees.

The geometric analysis of landscapes, still lifes and figurative compositions affirms the hypothesis that, in Cézanne's paintings, inverse space is prevalent, one that is created by slanting surfaces or objects towards the observer (Cézanne's wedge), through enlarging the background, using the effect of light and shadow, and most frequently by intersecting lines that are perpendicular to the painting's surface, situated in the same space as the observer.

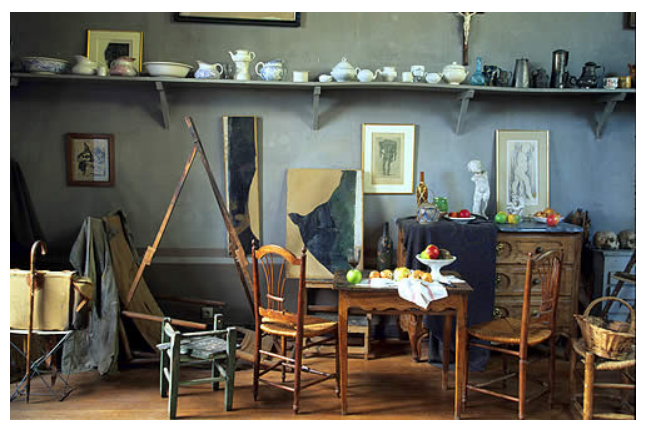

Figure 19. Cézanne's studio (Source: http://www.avignonet-provence.com/aix-en-provence/cezannestudio/\#.VyPtNvl95hE)

Cézanne didn't "escape" into the irrational, although many did. However, his unique genius was also in his determination to stay with his apples, ordinary bottles and almost ugly, mismatched plates. The fact that these objects, through his "truth in painting", have become the most beautiful we've ever seen or ever will see, helps us persevere in the not-at-all-simple attempt to answer the question "What is Cézanne's truth in painting"?

This paper needs to be understood as such.

\section{REFERENCES}

[1] Loran, E.: Cézanne's Composition, University of California Press, Barkley and Los Angeles, 1959.

[2] Đurić, J., et al.: The Patriarchate of Peć (Pećka patrijaršija), Jugoslovenska revija, Belgrade, 1990.
[3] Pipes, A.: Foundation of Art and Design, Laurence King Publishing Ltd, London, 2008.

[4] Schapiro, M.: Paul Cézanne, Harry N. Abrams, Inc, New York, 1963.

[5] Stavitsky, G., at al.: Cézanne and American Modernism. Montclair Art Museum, Baltimore Museum of Art, Yale University Press, New Haven and London, 2009.

[6] Trifunović, L.: Trends in the $20^{\text {th }}$ century Painting (Slikarski pravci XX veka), Prosveta, Beograd, 1994.

[7] Taylor, B.: Cézanne, Spring Book, London, 1961.

[8] Weltonová, J.: Eyewitness Art - Looking at Paintings (Jak Vnímat Obrazy), Dorling Kindersley and Perfekt, Bratislava, 1995.

[9] Williams, R.: Provence \& the Côte d'Azur, Dorling Kindersley Limited, London, 2014.

\section{ИНВЕРЗНА ПЕРСПЕКТИВА НА СЕЗАНОВОЈ СЛИЦИ}

\section{И. Марцикић, М. Пауновић}

У извесном смислу, коришћење Сезановог клипа представља модел инверзне перспективе употребљене за приказ простора и објеката на слици. Као мост између античке тзв. „подеоне конструкције“, односно „перспективе рибље кости“ и ренесансне перспективе, инверзна перспектива је важан пројекциони модел, посебно и због чињенице да у њој приказани објекти имају најмање заклоњених делова, а у поређењу са приказима у било ком другом пројекцијском систему. Оптичкофизиолошке особине очног апарата, чињеница да посматрамо простор из две тачке, чини да се инверзна перспектива коју карактеришу погледи из више парова тачака, приближава природном виђењу.

Фасцинација данашњег посматрача 3D простором на слици, удаљава стваралаштво уметника од његовог индивидуалног израза, његове интуитивне геометрије и његовог начина доживљаја реалности, што су иначе важне карактеристике сваког врхунског уметничког дела. У овом раду се проучава инверзна перспектива и њени визуелни ефекти примењени у простору Сезанове слике. 